\title{
ABOUT ONE RESOURCE CONTROL TASK AND OPTIMIZATION THROUGHPUT IN MULTISERVICE TELECOMMUNICATION NETWORKS
}

Vilayat M.Valiyev,

DOI: $10.36724 / 2072-8735-2020-\mid 4-6-48-52$

Azerbaijan Technical University, Baku, Azerbaijan, aztu@aztu.edu.az

Bayram G. Ibrahimov, Azerbaijan Technical University, Baku, Azerbaijan, i.bayram@mail.ru

Almaz A. Alieva, Mingechaur State University, Azerbaijan, almaz40@gmail.com

Keywords: Future networks, SDN, reliability, performance, fault tolerance, IMS, quality of service, security risk, NFV, efficiency, limited resources

\begin{abstract}
The analysis of the advantages using the architectural concept future networks FN (Future Networks), to build high-performance multiservice telecommunication networks (MTN), supporting a wide range multimedia services. A mathematical model MTS performance is proposed based on the architectural concept future FN networks using virtual, channel, information and network resources. The network performance model differs from the wellknown ones in that in order to ensure an acceptable quality of service QoS (Quality of Service) and QoE (Quality of Experience) perception in the common existing NGN architecture public multi-service networks, a new innovative technology and four target settings future networks were used FN. According to ITU-T, Y.300I and ITU-R, M. 2083-3 Recommendations, SDN (Software Defined Networking), NFV (Network Functions Virtualization), LTE (Long Term Evolution) and IMS (Internet Protocol Multimedia Subsystem)are proposed as the basis innovative technologies for building a multi-service network infrastructure (Internet Protocol Multimedia Subsystem), which will enable the organization optimal management and allocation throughput resources, and efficient network operation. Based on the proposed mathematical model, the complex MTS indices were studied, such as network throughput, efficient use virtualization network and information resources, probability-time characteristics of networks, structural reliability and information security, and economic efficiency and cost system hardware-software and terminal tools for multimedia rendering services. Analytical expressions are obtained for evaluating the integrated performance indicators MTN based on FN in the provision multimedia services. On the basis of the model, a numerical analysis was carried out and a graphical dependence of the maximum network bandwidth on the total number hardware and software systems and terminal means at a given system load factor was constructed. It was found that an increase in the total number hardware and software systems leads to an increase in the maximum throughput that meets the requirements QoS \& QoE for various services based on ETSI. Based on the analysis, actual problems are identified recommendations are developed to increase the efficiency using IntServ and DiffServ architectures for MTN.
\end{abstract}

Information about authors:

Vilayat Mammad Valiyev, Doctor of Technical Sciences, Professor, Azerbaijan Technical University, Bakuб Azerbaijan

Bayram Ganimat Ibrahimov, Doctor of Technical Sciences, Professor, Department of "Multichannel telecommunication systems", Azerbaijan Technical University, Baku, Azerbaijan

Almaz Ali Alieva, candidate of technical sciences, associate Professor, Mingechaur State University, Azerbaijan

Для цитирования:

Валиев В.М., Ибрагимов Б.Г., Алиева А.А. Задача управления ресурсами и оптимизации пропускной способности в мультисервисных телекоммуникационных сетях // Т-Сomm: Телекоммуникации и транспорт. 2020. Том I4. №6. С. 48-52.

For citation:

Valiyev V.M., Ibrahimov B.G., Alieva A.A. (2020) About one resource control task and optimization throughput in multiservice telecommunication networks. T-Comm, vol. I4, no.6, Pp. 48-52. (in Russian) 


\section{Introduction}

The rapid development of the infrastructure digital economy and the formation strategic plans for "Digitalization Roadmap" require new principles and qlobal approaches to building highly efficient MTN based on the architectural concept future networks FN with increase performance, using innovative technologies. These include primarily information and telecommunications technologies such as SDN, NFV, IMS, artificial intelligence, WDM \& DWDM (Wavelength Division Multiplexing \& Dense WDM), cloud computing, LTE mobile technologies, UMTS (Universal Mobile Telecommunications System), IoT (Internet of Think), as well as technologies for building distributed communication networks $[1,2,3]$.

Considering the proposed target settings for the creation future networks FN based on the recommendations of ITU-T, Y.3001 [3, 4, 5, 6] and the innovative technologies listed above, they open up new possibilities for providing a wide range basic, additional and intelligent services taking into account numerous requirements QoS and QoE parameters.

Therefore, the tasks analyzing MTN performance indicators based on the architectural concept FN using information and network resources are the most relevant. MTN performance is characterized by numerous complex indicators throughput, reliability, cost of the system and the efficiency using physical resources.

In this paper, we consider the solution of the problem formulated above - resource management and throughput optimization in multiservice telecommunication networks based on the architectural concept of future networks FN.

\section{General statement of the problem}

Given the importance building MTN based on FN [5] with packet switching (ITU-T, Y.3000 $\div$ Y.3499) heterogeneous traffic generating multimedia services and applications, special attention should be paid to complex performance indicators taking into account the numerous requirements QoS and QoE. However, based on the study $[5,7,8]$, it was established that transmitted heterogeneous traffic has a special structure - self-similarity properties. A quantitative estimate of the degree traffic selfsimilarity is the Hurst parameter $-H$.

Given the components of the vector, the MTN performance $E\left[\Pi\left(\lambda_{i}, H\right)\right]$ based on $\mathrm{FN}$ is functionally described by the following relationship:

$$
\begin{aligned}
& E\left[\Pi\left(\lambda_{i}, H\right)\right]=W\left[C_{\max }\left(\lambda_{i}\right), \eta_{e f}, K\left(\lambda_{i}, H\right), I_{r . s}\left(\lambda_{i}\right), C_{a n}^{\text {ว }}\left(\lambda_{i}\right)\right], \\
& i=\overline{1, k}
\end{aligned}
$$

where $C_{s s}^{e e}\left(\lambda_{i}\right)$ - economic efficiency and cost hardware and software systems and MTN terminal tools with the incoming stream intensity $\lambda_{i}$ while servicing the stream multimedia service $i$ - th traffic packets; $C_{\max }\left(\lambda_{i}\right)$ - maximum throughput FN based MTN based on speed $\lambda_{i}$ and coefficient $H$ when serving $i$ - th stream multimedia service traffic packets; $\eta_{e f}-$ coefficient of efficient use of heterogeneous resources; $K\left(\lambda_{i}, H\right)-$ a function that takes into account the requirements of the QoS \& QoE parameters taking into account the incoming flow rate $\lambda_{i}$ and coefficient $H$ when serving multimedia services; $I_{r s}\left(\lambda_{i}\right)-$ a function that takes into account indicators network reliability and information security, taking into account traffic intensity $\lambda_{i}$.

In (1), among the analyzed characteristics of networks, economic efficiency and the cost hardware and software systems occupy a special place $C_{a n}^{\text {ээ }}\left(\lambda_{i}\right)$ when using heterogeneous resources. A heterogeneous resource is the most important indicator used in the study of the performance communication networks.

However, the task managing heterogeneous resources, research and evaluating the performance MTN based on FN using innovative technologies while providing a wide range multimedia services has not yet been fully studied.

Given the statement of the problem, it is proposed MM performance MTN based on FN. MM takes into account the complex indicators networks under study, the essence of the new approach to managing heterogeneous resources innovative technologies and the effect of the self-similarity heterogeneous traffic on the characteristics service system.

\section{Description and construction of an analytical network model}

In order to build MTN, the use of the concept SDN, NFV and IMS [2-4] is taken into account as innovative technologies, which open up new opportunities for organizing effective network operation. To solve the problem under consideration, MM was proposed for the analysis MTN performance indicators and was selected as the objective function - economic efficiency and cost of the system, which is described by the following objective functions:

$$
E\left[\Pi\left(\lambda_{i}, H\right)\right]=\mathrm{W}\left\{\operatorname{Arg} \min _{i}\left[C_{s s}^{e e}\left(\lambda_{i}, H\right)\right]\right\}, i=\overline{1, k}
$$

with the following restriction

$$
\begin{aligned}
& N_{k} \leq N_{k . \text { доп. }}, E\left[T_{v}\left(\lambda_{i}\right)\right] \leq E\left[T_{\text {v.доп. }}\left(\lambda_{i}\right)\right] \\
& C_{\mathrm{i} . \text { max }} \leq C_{i . \max \text { доп. }}, \quad i=\overline{1, k}
\end{aligned}
$$

where $E\left[T_{v}\left(\lambda_{i}\right)\right]$ - average delay time during transmission of the $i$-th packet stream; $N_{k}$ - in the network node, the total number channels, hardware-software complexes and terminal means used;W-the operator of the joint transfer useful and service traffic; $C_{i \text {. max доn. }}, E\left[T_{v \text {.доn. }}\left(\lambda_{i}\right)\right], N_{k \text {.доп. }}-$ ac ordingly, the permissible value of the throughput, the average delay time and the number channels, hardware and software systems when transmitting the $i$-th traffic stream, $i=\overline{1, k}$.

Expressions (2) and (3) determine the nature of the considered MM performance MTN based on FN when providing a variety multimedia services. 


\section{Resource management efficiency in MTN}

Assume that a heterogeneous poisson stream traffic packets with parameters arrives at the buffer drive of the switch and controller with the OpenFlow protocol $\lambda_{i}, i=\overline{1, k}$, created by various types load sources $[2,6,9]$, generated by infocommunication services (service loads $\lambda_{i . n}$ and also useful $\lambda_{i . c}$ ). In this system, the switch and controller with the OpenFlow protocol is the central node of the SDN network, which makes decisions on all routing issues. $\mathrm{MM}$ in the ceneral case is a multichannel queuing system of a general type with queues are considered. This system has a common buffer storage with capacity $N_{b s}$ and maximum number serving hardware-software systems and terminal facilities $N_{k}$. At the same time, the duration packet stream service has a distribution function $B(t)=P[B \leq t]$ with moments $b_{i}$, $i=\overline{1, k}$. Moreover, a condition that is necessary and sufficient for the existence of a stationary mode of the system is as follows:

$$
\rho=\sum_{i=1}^{k}\left[b_{i} \cdot\left(\lambda_{i . n}+\lambda_{i . c}\right) / N_{k}\right] \cdot f\left(H_{i}\right) \leq 1, \quad i=\overline{1, k},
$$

where $f\left(H_{i}\right)$ - a function that takes into account the selfsimilarity of the incoming load and determines the Hurst coefficient for the stream $i$-th traffic packet, $H_{i} \in(1 / 2 ; 1)$.

One of the key characteristics for evaluating the performance MTN based on FN is their maximum throughput. Under the conditions permissible load $\rho_{i . \text { on. }}$, the maximum network throughput when servicing the $i$-th stream of the packet of self-similar traffic is determined by the following expression:

$$
\begin{aligned}
& C_{i . \max }\left(\lambda_{i}, \rho_{i} \leq \rho_{i . \partial o n .}\right)=\frac{N_{k}}{E\left[L_{i . n}\right]} \cdot E[V] \times, \\
& \times\left(\rho_{i . \text {. } x}+\rho_{i . u c x}\right) \cdot f\left(H_{i}\right) \leq C_{i . \max . \text {.on. }}\left(\lambda_{i}\right) \\
& i=\overline{1, k}
\end{aligned}
$$

where $\rho_{i .8 x}, \rho_{i . u c x}-$ accordingly, the load factor incoming and outgoing network channels when servicing the $i$-th packet stream and $\rho_{i . b x} \leq \rho_{i . u c x} ; E\left[L_{i . n}\right]-$ the average length of the transmitted i-th stream of the packet, $i=\overline{1, k}$.

From (4) and (5) it can be seen that the maximum value network throughput, depending on the parameters $E[V], f(H)$ and $N_{k}$ under a given condition, the load $\rho$ factor is limited. This means that restrictions are also set on the total cost of the network under study, because the $C_{i \text { max }}$ directly depends $C_{s s}^{e e}\left(\lambda_{i}\right)$.

Figure 1 shows a graphical dependence of the maximum throughput on the total number hardware and software systems and terminal tools for a given system load factor $\rho$ and Hurst coefficient, $H_{i}=(0,60, \ldots, 0,75)$.
Graphical dependency analysis $C_{\max }=F\left[\rho, N_{k}, f(H),\right]$ that an increase in the total amount leads to $C_{\max } \geq 450, \ldots, 600$ Mbps systems, QoS\&QoE compliant for various services. Its noticeable change begins with $N_{k} \geq(450, \ldots, 500)$ a value at $\rho \geq 0,65$. Moreover, the gain in throughput is manifested along with the gain in the noise immunity of the communication system.

\section{Analysis of the reliability and information security indicator MTN}

The following important characteristics were selected as a criterion of indicators of system reliability and information security: average time between failures, attack threats with the intensity occurrence $\lambda_{a}$, intensity elimination $\mu_{a}$ of the real threat attack, and the parameter failure flow $\Lambda_{n o}$.

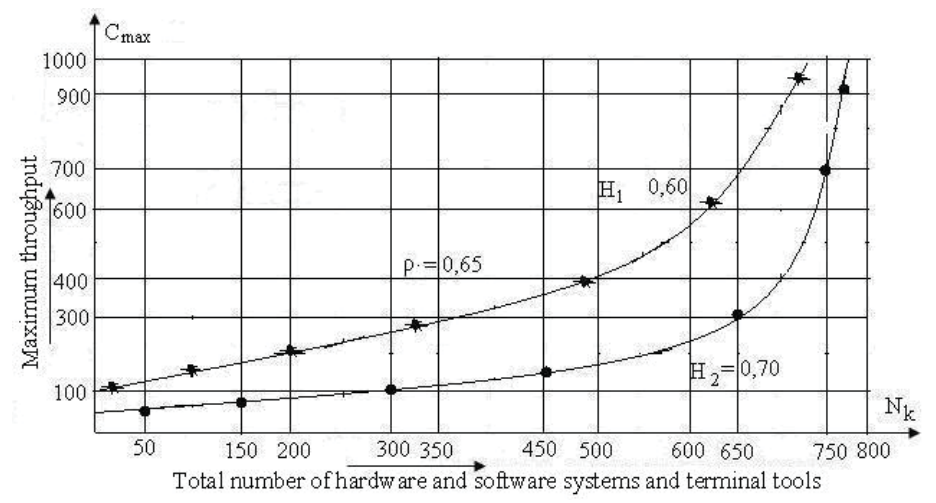

Fig. 1. Graphic dependence of the maximum throughput MTN based on FN on the total number hardware and software systems and terminal tools

Based on the reliability model, the failure flow parameter $\lambda_{n o}$ for the stationary section is found by the following expression $[8,9]$ :

$$
\lambda_{n o}=\sum_{i \in Q_{p c}} P_{i} \cdot \sum_{i \in Q_{o c}} \Lambda_{i j}
$$

where $Q_{p c}$ - many health conditions MTN based on FN; $Q_{o c}-$ many MTN failure conditions and equal $Q_{o c}=1-Q_{p c} ; \Lambda_{i j}-$ the intensity of the transition from $i$-th working state, the probability of finding the system $P_{i}$ in which $j-$ th inoperative state.

In order to evaluate information security parameters, the following important characteristics of the threat of attack were selected, which are expressed by the following formulas $[9,10]$ :

$$
\lambda_{a}=1 / E\left[T_{y a}\right], \quad \mu_{a}=\lambda_{a} \cdot P_{a} \cdot\left(1-P_{a}\right)
$$

where $E\left[T_{y a}\right]$ - average network failure time; $P_{a}$ - the probability of readiness for safe operation of the protected information system when changing the security parameters of the protection system $\lambda_{a}$ and $\mu_{a}$ communication networks. 
Based on (6) and (7), it is possible to determine the stationary coefficient $K_{k}$ of system availability during the safe operation hardware-software complexes networks:

$$
K_{k}=E\left[T_{y a}\right] / \lambda_{n o}
$$

Expression (8) is one of the important integral characteristics MTN based on the architectural concept FN, which is necessary so that the information protection system does not introduce large service delays.

\section{Studies of the probability-time characteristics MTN networks}

Given the features stochastic MM parameters $\lambda_{i}, d$ (d-intensity network recovery) $\mu$ and $N_{k}$ the average delay time when serving flows of the $i$-th packet self-similar traffic in MTN is determined as follows [9]:

$$
\begin{aligned}
& E\left[T_{v}\left(\lambda_{i}\right)\right]=\frac{\rho_{i} \cdot N_{k}}{\lambda_{i} \cdot K_{k}\left(1-\rho_{i}\right)} \cdot\left[1+\frac{\mu \cdot K_{k}}{d} \cdot\left(1-K_{k}\right)\right] \cdot f\left(H_{i}\right), \\
& i=\overline{1, k}
\end{aligned}
$$

Expression (9) shows one of the important probability-time characteristics of the MTN for a given algorithm "End to end" the total transmission delay of the $i$ - th streams packet selfsimilar traffic. Minimization of the value $E\left[T_{v}\left(\lambda_{i}\right)\right]$ has a significant impact on QoS \& QoE, fault-tolerance and information security of the systems.

\section{Conclusions}

As a result of the study, MM MTN performance based on FN was proposed using innovative technologies that take into account network performance indicators, control and resources allocation methods, and self-similarity properties heterogeneous traffic. Based on the model, analytical expression have been obtained to evaluate indicators throughput, system reliability, information security and the probability-time characteristics networks in the provision multimedia service, which ensure the guaranteed QoS \& QoE, regulated by ITU-T, Q.1541.

Graphic dependence analyzed $C_{\max }=F\left[\rho, N_{k}, f(H),\right]$ it was found that a strong dependence $C_{\max }$ on the total number $N_{k}$ is the main drawback MTN based on the architectural concept FN using SDN \& NFV and IMS technology. As a result, the reliability of the network and the protection against unauthorized access along the perimeter of the subscriber and communication network lines are deteriorating.

\section{References}

1. Efimushkin V.A., Ledoko kikh T.V., Ivanov A.B., Shalaginov V.A. (2018).The role of SDN / NFV technologies in the digital economy infrastructure. Experience of testing and implementation. Electrosvyaz, No.3, pp. 27-36.

2. Mukhizi S. Muthanna A.S., Krichek R.V., Kucheryavy A.E. (2019). Study of load balancing models in software-defined networks. Electrosvyaz, No. 1, pp. 23-29.

3. brahimov B.G., Humbatov R.T., Ibrahimov R.F. (2018). Analysis performance multiservice telecommunication networks with using architectural concept future networks. T-Comm, vol.12, No.12, pp. 84-88.

4. Pshenichni v A.P. (2019). Stages digitalization communication networks. Methodological issues teaching infocommunications in higher education. No. 2, pp. 65-71.

5.Ibrahimov B.G., Humbatov R.T., Ibrahimov R.F., Isaev A.M. (2019). Analysis indicators of the performance multiservice telecommunication networks future generation using the technologies softwaredefined networks. Journal of Computer and Information Technology, No.5, pp. 39-44.

6. Bian , B., Fajordo J.O., Cianonoulakis et.all. (2017).Technology pillars in the architecture of future 5G mobile networks: NFV, MEC and SDN. Computer Standarts \& Interfaces. Vol. 54, Part 4, pp. 216-228.

7. Shelukh O.I. (2018). Modeling information systems. Moscow: Hot line-Telecom. 516 p.

8. Polov A.M., Gurov S.V. (2006). Fundamentals of the theory of reliability. SPb.: BHV - Peterburg .- 704 p.

9. Ibr imov B.G., Hasanov A.G., Alieva A.A., Isaev A.M. (2019). The study performance indicators multiservice telecommunication networks based on the architectural concept of future networks. Reliability and quality of complex systems. No.1 (25), pp. 88-95.

10. S eglov K. A., Shcheglov A. Yu. (2016). Interpretation and modeling of the threat attack on the information system. Part 2. Modeling the threat of attack. Information Technology. Vol. 22. No. 1, pp. 54-64. 


\section{ЗАДАЧА УПРАВЛЕНИЯ РЕСУРСАМИ И ОПТИМИЗАЦИИ ПРОПУСКНОЙ СПОСОБНОСТИ В МУЛЬТИСЕРВИСНЫХ ТЕЛЕКОММУНИКАЦИОННЫХ СЕТЯХ}

Валиев Вилаят Мамед оглы, Азербайджанский Технический Университет, Баку, Азербайджан, aztu@aztu.edu.az

Ибрагимов Байрам Ганимат оглы, Азербайджанский Технический Универсuтеm, Баку, Азербайджан, i. bayram@mail.ru Алиева Алмаз Али кызы, Мингечаурский Государственный университет, Азербайджан, almaz40@gmail.com

\section{Аннотация}

Проведен анализ преимущества использования архитектурной концепции будущих сетей FN (Future Networks) для построения высокоэффективных мультисервисных телекоммуникационных сетей (МТС), поддерживающих широкий спектр мультимедийных услуг. Предложена математическая модель (MM) производительности MTC на базе архитектурной концепции FN, использующие виртуальные, канальные, информационные и сетевые ресурсы. Модель производительности сетей, отличается от известных тем, что для обеспечения приемлемого качества обслуживания QoS (Quality of Service) и качества восприятия QoE (Quality of Experience) в общей существующей NGN архитектуре мультисервисных сетей общего пользования была использована новая инновационная технология и четыре целевых установки Будущих сетей FN. Согласно Рекомендации ITU-T, Y.300I и ITU-R, M.2083-3 для построения мультисервисной сетевой инфраструктуры в качестве базовых инновационных технологий предлагается использование SDN (Software Defined Networking), NFV (Network Functions Virtualization), LTE (Long Term Evolution) и IMS (Internet Protocol Multimedia Subsystem), что даст возможность организации оптимального управления и распределения ресурсами пропускной способности, и эффективной работы сети. На базе предложенной математической модели исследованы комплексные показатели МТС как пропускная способность сетей, эффективное использование виртуализации сетевых и информационных ресурсов, вероятностновременные характеристики сетей, структурная надёжность и информационная безопасность, так и экономическая эффективность и стоимость аппаратно-программных и терминальных средств системы при оказании мультимедийных услуг. Получены аналитических выражения для оценки комплексных показателей производительности МТС на базе FN при оказании мультимедийных услуг. На базе модели был проведен численный анализ и построена графическая зависимость максимальной пропускной способности сетей от общего числа аппаратно - программных комплексов и терминальных средств при заданном коэффициенте загрузки системы. Установлено, что увеличение общего числа аппаратно-программных комплексов, приводит к повышению максимальной пропускной способности, отвечающей требованиям QoS\&QoE для различных услуг на базе ETSI. На основе проведенного анализа обозначены актуальные проблемы и разработаны рекомендации по повышению эффективности применения архитектур IntServ и DiffServ для MTC.

Ключевые слова: будущие сети, SDN, надежность, производительность, отказоустойчивость, IMS, качество обслуживании, угроза безопасности, NFV, эффективность, ограниченные ресурсы.

\section{Литература}

І. Ефимушкин В.А., Ледовских Т.В., Иванов А.Б., Шалагинов В.А. Роль технологий SDN/NFV в инфраструктуре цифровой экономики. Опыт тестирования и внедрения // Электросвязь, №3. 2018. С. 27-36.

2. Мухизи С., Мутханна А.С., Кричек Р.В., Кучерявый А.Е. Исследование моделей балансировки нагрузки в программноконфигурируемых сетях// Электросвязь. 2019. №І. С. 23-29.

3. Ibrahimov B.G., Humbatov R.T., Ibrahimov R.F. (2018). Analysis performance multiservice telecommunication networks with using architectural concept future networks // T-Comm: Телекоммуникации и транспорт, vol.12, No.12. pp. 84-88.

4. Пшеничников А.П. Этапы цифровизации сетей связи // Методические вопросы преподавании инфокоммуникаций в высшей школе. №2, 2019. С. 65-7I.

5. Ибрагимов Б.Г., Гумбатов Р.Т., Ибрагимов Р.Ф., Исаев А.М. Анализ показателей производительности мультисервисных телекоммуникационных сетей будущего поколения с использованием технологий программно-конфигурируемых сетей // Вестник компьютерных и информационных технологии, № 5, 2019. С. 39-44.

6. Bianco, B., Fajordo J.O., Cianonoulakis et.all. Technology pillars in the architecture of future $5 \mathrm{G}$ mobile networks: NFV, MEC and SDN// Computer Standarts \& Interfaces. 2017. Vol. 54, Part 4. pp. 216-228.

7. Шелухин О.И. Моделирования информационных систем. М.: Горячая линия - Телеком. 2018.516 с.

8. Половко А.М., Гуров С.В. Основы теории надежности. СПб.: БХВ - Петербург, 2006. 704 с.

9. Ибрагимов Б.Г., Гасанов А.Г., Алиева А.А., Исаев А.М. Исследование показателей качества функционирования мультисервисных телекоммуникационных сетей на базе архитектурной концепции будущих сетей // Надежность и качество сложных систем. 2019. № I (25). С. 88-95.

І0. Щеглов К.А., Щеглов А.Ю. Интерпретация и моделирование угрозы атаки на информационную систему. Часть 2. Моделирование угрозы атаки // Информационная технологии, Том 22. №I. 2016. С. 54-64.

Информация об авторах:

Валиев Вилаят Мамед оглы, д.т.н., профессор Азербайджанского Технического Университета, Баку, Азербайджан, Ибрагимов Байрам Ганимат оглы, д.т.н., профессор Азербайджанского Технического Университета, Баку, Азербайджан

Алиева Алмаз Али кызы, к.т.н., доцент Мингечаурского Государственного университета, Азербайджан 